\title{
WHY DO COMPETING BUSINESSES OPEN UP NEXT TO ONE ANOTHERP NASH EQUILIBRIUM IN OPENING HYPERMARKETS IN BUGHAREST
}

\author{
Cristina STOICESCU ${ }^{\mathrm{a} *}$ \\ a) Bucharest University of Economic Studies, Economic Cybernetics and Statistics, \\ Bucharest, Romania
}

Please cite this article as:

Article History:

Stoicescu, C., 2018. Why do competing businesses open up next to one another? Nash Equilibrium in opening hypermarkets in Bucharest. Review of Economic Studies and Research Virgil Madgearu, 11(1), pp.75-96.

doi: 10.24193/RVM.2018.11.22.

\begin{abstract}
Modern Game Theory can be applied in various social and economic situations where the decision made by a single individual is based on the decisions made by others. Companies started to apply these principles in making different management decisions, like opening a new retail center. This paper focuses on the study of the rationale behind the decision of opening a new food retail store very close to the main competitors by applying the Nash Equilibrium in a normal form game with complete information and its extension to the Hotelling model. Early 2017, 36 hypermarkets were operating in Bucharest (Kaufland, Cora, Auchan and Carrefour), all located at a minimum average distance of 2,83 $\mathrm{km}$ from one another. Each store serves more than 50.000 people. Most of the stores are placed in the south side of the city. Kaufland is the chain with the highest market share and operating profit in Romania, having the most stores in proximity of other competitors.
\end{abstract}

Key words: consumer behavior; hypermarket; Hotelling model; Nash Equilibrium JEL Classification: $C_{72}$; $D 12$

(C) 2018 Alma Mater Publishing House. All rights reserved.

* Corresponding author. E-mail address: kris_stoicesku@yahoo.com. 


\section{References}

1. Akalin, M., Turhan, G. and Sahin, A., 2013. The Application of AHP Approach for Evaluating Location Selection. Elements for Retail Store: A Case of Clothing Store. International Journal of Research in Business and Social Sciences, 2(4), pp.1-20.

2. Christaller, W., 1933. The Central Places of Southern Germany. Fischer, Jena.

3. Cramer, E.R., 1973. The Alpha Beta Story: An Illustrated History of a Leading Western Food Retailer. Alpha Beta Acme Markets, SUA.

4. Holt, C.A. and Roth, A.E., 2004. The Nash equilibrium: A perspective. Proceedings of the National Academy of Sciences of the United States of America, 101(12), pp.3999-4002.

5. Hotelling, H., 1929. Stability in Competition. Economic Journal, 39, pp. 41-57.

6. Huff, D., 1964. Defining and Estimating a Trading Area. Journal of Marketing, 28, pp.34-38.

7. Li, Y. and Liu L., 2012. Assessing the impact of retail location on store performance: A comparison of Wal-Mart and Kmart stores in Cincinnati. Applied Geography, 32(2), pp.591-600.

8. Myerson, R.B., 1991. Game Theory: Analysis of Conflict. Harvard Univ. Press, pp.vii-xi.

9. Neumann, J., Morgenstern, O., 1994. Theory of Games and Economic Behavior. Princeton Univ. Press, pp.10-30.

10. Nash, J.F., 2950. Equilibrium Points in n-Person Games. Proceedings of the National Academy of Sciences of the United States of America, 26(1), pp.48-49.

11. Neven D., 1985. Two Stage (Perfect) Equilibrium in Hotelling's Model. The Journal of Industrial Economics, 33(3), pp.317-325.

12. Reilly, W.J., 1931. The law of retail gravitation. New York: Knickerbocker Press.

13. Roman, M., Marin, D. and Stancu, S., 2005. Teoria Jocurilor pentru economişti. Bucurrești: ASE Publishing House.

14. Salop, S.C., 1979. Monopolistic Competition with Outside Goods. The Bell Journal of Economics, 10(I), pp.141-156.

15. Teller, C., Alexander, A., Floh, A., 2016. The impact of competition and cooperation on the performance of a retail agglomeration and its stores. Industrial Marketing Management, 52, pp.6-17. 
16. INS, 2017. Bucharest demographic structure, Available at: <http:// www.insse.ro/cms/> [Accessed 23 January 2017].

17. GfK, 2017. Puterea de cumpărare este în creştere în România, Available at: <http://www.gfk.com/ro/noutati/comunicate-depresa/puterea-de-cumparare-este-in-crestere-in-romania/> [Accessed 20 March 2017].

18. Marinescu, C., 2015. Supermarketul, locul preferat de cumpărături pentru $83 \%$ dintre români; 66\% prefer produsele alimentare româneşti (studiu). AGERPRES, Available at: <https://www. agerpres.ro/economie/2015/10/07/> [Accessed 12 February 2017].

19. Nielsen, 2015. The future of grocery. E-commerce, digital technology and changing shopping preferences around the world. [online] Available at: <https://www.nielsen.com/content/dam/ nielsenglobal/vn/docs/Reports/2015/> [Accessed 15 March 2017]. 